\title{
Coupling technique of random amplified polymorphic DNA and nanoelectrochemical sensor for mapping pancreatic cancer genetic fingerprint
}

\author{
This article was published in the following Dove Press journal: \\ International Journal of Nanomedicine \\ 18 November 2011 \\ Number of times this article has been viewed
}

\author{
Qicai Liu ${ }^{1,2}$ \\ Ailin $\mathrm{Liu}^{3,4}$ \\ Feng $\mathrm{Gao}^{5}$ \\ Shaohuang Weng ${ }^{3,4}$ \\ Guangxian Zhong, \\ Jingfeng Liu $^{6}$ \\ Xinhua $\operatorname{Lin}^{3,4}$ \\ Jian-hua $\operatorname{Lin}^{7}$ \\ Xuhai Chen ${ }^{8}$ \\ 'Department of Laboratory Medicine, \\ Fujian Medical University, Fuzhou, \\ ${ }^{2}$ Department of Gene Diagnosis, Fujian \\ Medical University, Fuzhou, ${ }^{3}$ Department \\ of Nano-Biomedical Research Center, \\ Fujian Medical University, Fuzhou, \\ ${ }^{4}$ Department of Pharmaceutical Analysis, \\ Fujian Medical University, Fuzhou, \\ ${ }^{5}$ Department of Pathology, Fujian \\ Medical University, Fuzhou, ${ }^{6}$ Department \\ of Surgery, Fujian Medical University, \\ Fuzhou, ${ }^{7}$ Department of Bone Oncology, \\ First Affiliated Hospital, Fujian Medical \\ University, Fuzhou, ${ }^{8} \mathrm{College}$ of Electrical \\ Engineering and Automation, Fuzhou \\ University, Fuzhou, People's Republic \\ of China
}

Correspondence: Xinhua Lin Department of Pharmaceutical Analysis, Fujian Medical University, Fuzhou 350005. People's Republic of China Tel +86 59l 83324II6

Email lqc673@yahoo.com.cn or xhl1963@sina.com

Jian-hua Lin

Department of Bone Oncology, First Affiliated Hospital, Fujian Medical University, Fuzhou 350005,

People's Republic of China

Tel +86 59l 83357।99

Email shenghua2327@yahoo.cn
Objective: To review the feasibility of coupling the techniques of random amplified polymorphic DNA (RAPD) with carbon nanotube-based modified electrode for guanine/deoxyguanine triphosphate (dGTP) electrochemical sensing for mapping of the pancreatic cancer genetic fingerprint and screening of genetic alterations.

Methods: We developed a new method to study the electrochemical behavior of dGTP utilizing carbon multiwalled nanotube (MWNT)-modified glassy carbon electrodes (GCEs). RAPD was applied for amplification of DNA samples from healthy controls and patients with pancreatic cancer under the same conditions to determine the different surplus quantity of dGTP in the polymerase chain reaction (PCR), thereby determining the difference/quantity of PCR products or template strands. Using this method we generated a genetic fingerprint map of pancreatic cancer through the combination of electrochemical sensors and gel electrophoresis to screen for genetic alterations. Cloning and sequencing were then performed to verify these gene alterations.

Results: dGTP showed favorable electrochemical behavior on the MWNTs/GCE. The results indicated that the electrical signal and dGTP had a satisfactory linear relationship with the dGTP concentration within the conventional PCR concentration range. The MWNTs/GCE could distinguish between different products of RAPD. This experiment successfully identified a new pancreatic cancer-associated mutant gene fragment, consisting of a cyclin-dependent kinase 4 gene $3^{\prime}$ terminal mutation.

Conclusion: The coupling of RAPD and nanoelectrochemical sensors was successfully applied to the screening of genetic alterations in pancreatic cancer and for mapping of DNA fingerprints.

Keywords: nanoelectrochemical sensor, random amplified polymorphic DNA, genetic fingerprint, pancreatic cancer, genetic predisposition, carbon nanotube

\section{Introduction}

The high lethality rate of pancreatic cancer necessitates further improvement of therapeutic modalities, and it is clinically urgent to find new means to accurately detect early development of pancreatic cancer. Besides environmental exposure, genetic susceptibility to pancreatic cancer is also recognized as an important factor influencing the development of the disease in different individuals. As such, the identification of genetic differences related to the development of pancreatic cancer could lead to significant breakthroughs in early diagnosis and treatment. ${ }^{1-3}$

Electrochemical biosensing technology, which is characterized by high efficiency and sensitivity, easy and simple operation, and zero contamination, has been employed 
in molecular recognition and separation as well as in gene purification, and it is currently a cutting-edge research field in the life sciences. ${ }^{4-7}$ Carbon nanotubes demonstrate good electrical properties, nanosize effects, large specific surface areas, and favorable biocompatibility, and they are widely used in electrochemical biosensing technology. ${ }^{8-11}$ Carbon nanotube-modified glassy carbon electrodes (GCEs) can be used for simultaneous determination of deoxyguanine triphosphate (dGTP) and guanine, providing the possibility for direct detection of dGTP without separation of polymerase chain reaction (PCR) products. This study screened for gene mutations associated with pancreatic cancer by employing the techniques of arbitrarily primed PCR (random amplified polymorphic DNA [RAPD]) and electrochemistry to detect dGTP. It has been shown that RAPD, which employs random short-sequence primers, can be used to generate gene maps and is not limited to the detection of specific gene mutations or polymorphisms. ${ }^{12}$ This study applied these new methods to achieve genetic fingerprinting of pancreatic cancer, overcoming the limitations of traditional RAPD and improving the screening efficiency to create a technology platform for screening of genetic susceptibility to complex diseases. These results have far-reaching scientific significance.

\section{Material and methods}

\section{Instrument and reagents}

The Model CHI 660C electrochemical analyzer (Shanghai Chenhua Instruments, Shanghai, People's Republic of China) adopts a three-electrode system. The working electrode is a carbon multiwalled nanotube (MWNT)-modified GCE, the counter electrode is a platinum wire electrode, and the reference electrode is an $\mathrm{Ag} / \mathrm{AgCl}$ electrode (saturated $\mathrm{KCl}$ ). The following reagents were used in this study: MWNTs with a purity of $>95 \%$, an inside diameter of $<10 \mathrm{~nm}$, 5-15 $\mu \mathrm{m}$ length, ash content $<0.2 \mathrm{wt} \%$, and a unit surface area of 40-300 m²/g (Nano-Tech Port, Shenzhen, People's Republic of China); dGTP (SBS Genetech, Beijing, People's Republic of China); guanine (Oxoid, Hampshire, UK); and N,N-dimethyl formamide (DMF; Ruijinte Chemicals, Tianjin, People's Republic of China). All reagents used were analytically pure, and all solutions were prepared with secondary quartz distilled water, with $10 \times$ PCR buffer and $\mathrm{MgCl}_{2}$ (Promega, Madison, WI) used for PCR. Detection of dGTP in the proof sample and in the arbitrarily primed PCR reaction utilized the electrochemical work station described previously.

\section{Carbon nanotube activating treatment}

A total of $1 \mathrm{~g}$ of carbon nanotubes was placed in a concentrated sulfuric acid-nitric acid (volume ratio 3:1) mixture $(100 \mathrm{~mL})$ and heated and stirred at a constant temperature of $70^{\circ} \mathrm{C}$ for 12 hours. The solution was then filtered and washed until the $\mathrm{pH}$ value of the cleaning solution reached 7.0 and then subjected to vacuum drying at $60^{\circ} \mathrm{C}$ for 24 hours to obtain carboxylated carbon nanotubes.

\section{Preparation of carbon nanotube-modified GCE}

The GCE was successively polished in $0.30 \mu \mathrm{m}$ and $0.05 \mu \mathrm{m}$ $\mathrm{Al}_{2} \mathrm{O}_{3}$ and then subjected to ultrasonic cleaning for 3 minutes in 1:1 nitric acid, absolute ethyl alcohol, and redistilled water. It was then dried with nitrogen gas for later use. A quantity of carboxylated carbon nanotubes were placed into a spherical flask, sterilized deionized water was added, and ultrasonic dispersion was performed for 45 minutes to prepare a $1 \mathrm{mg} / \mathrm{mL}$ carbon nanotube dispersion. A total of $8 \mathrm{~mL}$ of dispersion was applied on to the surface of the GCE, and the electrode was fixed in a vacuum dryer. A GCE with a uniform layer of MWNTs was thus obtained.

\section{Electrochemical behavior of dGTP on the MWNTs/GCE}

Different concentrations of the dGTP proof sample were added into the PCR buffer. Enrichment was then performed for 2 minutes with constant stirring. The oxidation currents of the different concentrations of dGTP were measured using cyclic voltammetry and pulse differential indication methods. Before testing, nitrogen gas was supplied to the electrolytic cell for 5 minutes, so as to remove the dissolved oxygen. The standard curve was generated based on the electrical signals and dGTP concentrations.

\section{RAPD amplification of DNA samples from patients and healthy controls}

Primer design and RAPD amplification conditions are indicated in Table 1.

\section{Arbitrarily primed PCR amplification}

DNA templates of patient and healthy control groups were diluted to the same concentration, and amplification was perform based on the following conditions by using the random primers detailed in Table 1 . The $50 \mu \mathrm{L}$ reaction mixture contained $200 \mathrm{ng}$ of genomic DNA, $10 \mathrm{mmol} / \mathrm{L}$ Tris $\mathrm{HCl}$ 
Table I List of random primers ${ }^{\mathrm{a}}$

\begin{tabular}{|c|c|c|}
\hline $\begin{array}{l}\text { Primer } \\
\text { number }\end{array}$ & $\begin{array}{l}\text { Primer } \\
\text { sequence }\end{array}$ & $\begin{array}{l}\text { Random primers } \\
\text { combination mode }\end{array}$ \\
\hline $\mathrm{I}$ & CCGGCTACG & $\mathrm{I}, 2,3,4,5,6,7,8,9$ \\
\hline 2 & AACGGTCACT & $\mathrm{I}-2,2-3,3-4,4-5,5-6,6-7,7-8,8-9$ \\
\hline 3 & CCTGCACTGC & $\mathrm{I}-3,2-4,3-5,4-6,5-7,6-8,7-9$ \\
\hline 4 & GGTCTGAACC & $\mathrm{I}-4,2-5,3-6,4-7,5-8,6-9$ \\
\hline 5 & AAGGCTAACG & $\mathrm{I}-5,2-6,3-7,4-8,5-9$ \\
\hline 6 & CTTGATTGCC & $1-6,2-7,3-8,4-9$ \\
\hline 7 & CTGATCCATG & $\mathrm{I}-7,2-8,3-9$ \\
\hline 8 & CTTGATTGGG & $1-8,2-9$ \\
\hline 9 & CTGCTCTCAGA & $1-9$ \\
\hline
\end{tabular}

(pH 9.0), $50 \mathrm{mmol} / \mathrm{L} \mathrm{KCl,} 0.1 \%$ Triton, $2 \mathrm{mmol} / \mathrm{L} \mathrm{MgCl}_{2}$, $0.25 \mathrm{mmol} / \mathrm{L} \mathrm{dNTPs}, 100 \mathrm{ng}$ of sense primer, $100 \mathrm{ng}$ of antisense primer, and 3.0 U Taq-DNA polymerase. Cycling conditions included an initial step at $94^{\circ} \mathrm{C}$ for 5 minutes; 45 cycles of $94^{\circ} \mathrm{C}$ for 1 minute, $36^{\circ} \mathrm{C}$ for 1 minute, and $72^{\circ} \mathrm{C}$ for 2 minutes; and a final elongation step at $72^{\circ} \mathrm{C}$ for 7 minutes. PCR products ( $10 \mu \mathrm{L})$ were separated using $1.5 \%$ agarose gel electrophoresis.

\section{Cloning and sequencing}

On the basis of the results obtained using the nanobiosensors, significant differences in surplus dGTP were determined. We then analyzed the remaining PCR products (pancreatic cancer and healthy control groups) by agarose gel electrophoresis. After separating and purifying the differential PCR fragments, the fragments were ligated into the pMD18-T plasmid (TaKaRa Bio, Shiga, Japan). The ligation reactions were transformed into Escherichia coli DH5 competent cells and incubated for 24 hours. The isolated plasmids were sequenced using an ABI PRISM7700 sequencer (Sangong Biotech, Shanghai, People's Republic of China). The sequences were then compared with the human genomic sequence (NCBI, Bethesda, MD).

\section{Results \\ Detection of guanine and dGTP}

There was a significant difference between the oxidation peak potentials of dGTP and guanine, as determined using the MWNTs/GCE (see Figure 1). The oxidation peak of dGTP was about $1.0 \mathrm{~V}$, and that of guanine was between $0.65 \mathrm{~V}$ and $0.70 \mathrm{~V}$, which was consistent with previously published observations. ${ }^{5}$ This indicated that the MWNTs/GCE could effectively distinguish between the oxidation peak potentials of dGTP and guanine, making it possible to selectively detect

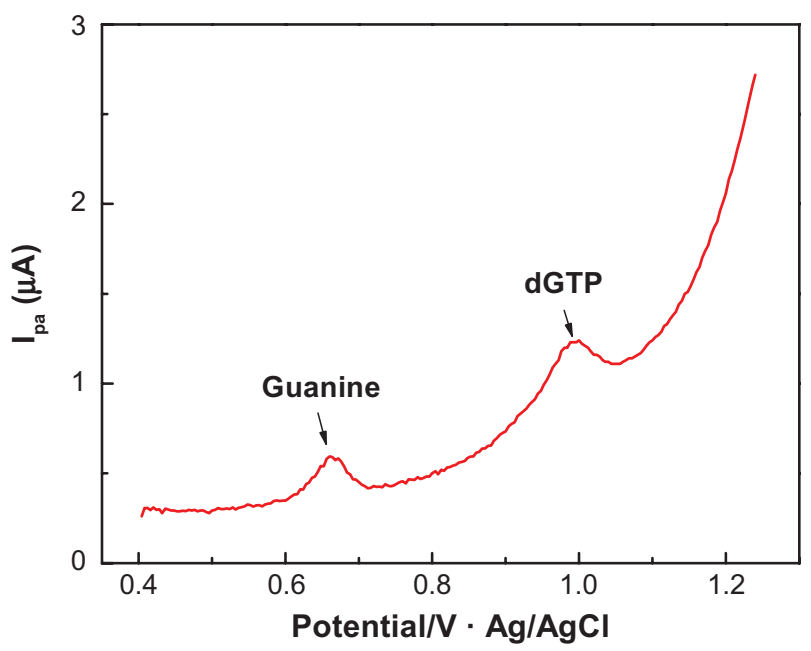

Figure I DPV diagram of $20 \mu \mathrm{mol} / \mathrm{L}$ guanine and $20 \mu \mathrm{mol} / \mathrm{L}$ deoxy-guanine triphosphate on multiwalled nanotube-modified glassy carbon electrode.

Abbreviations: dGTP, deoxy-guanine triphosphate; DPV, differential pulse voltammetric.

the composition within the PCR system without separation of the reaction products.

\section{Different concentrations of dGTP demonstrated a favorable linear relationship}

As is shown in Figure 2, the oxidation peak current of dGTP increased with the increasing concentration. Within the range of 5-50 $\mu \mathrm{mol} / \mathrm{L}$, the oxidation peak current of dGTP showed a perfect linear relation with concentration, with a regression

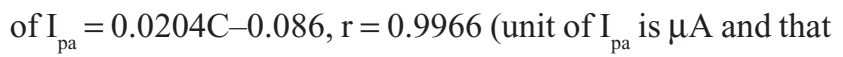
of $\mathrm{C}$ is $\mu \mathrm{mol} / \mathrm{L}$ ). This experiment showed that the MWNTs/ GCE could effectively detect changes in dGTP concentration in the PCR system and could be used to screen for genetic alterations amplified using random primers.

\section{Analysis of gene mutations}

As is shown in Figure 3A, compared with the healthy control, the concentration of dGTP in the peripheral blood DNA of patients with pancreatic cancer changed remarkably after 40 cycles of amplification, and the peak current difference was $0.33 \mu \mathrm{A}$. It could be estimated based on the linear equation obtained from Figure 2 that the dGTP concentration consumed in the reaction for the patients with pancreatic cancer was $23.8 \mu \mathrm{mol} / \mathrm{L}$ higher than the healthy control (theoretically, when consuming $20 \mu \mathrm{mol} / \mathrm{L}$ of dGTP, a $50 \mu \mathrm{L}$ reaction would be able to synthesize $250 \mathrm{ng}$ or $1.25 \mathrm{pmol}$ of an $800 \mathrm{bp}$ sequence).

It can be observed from the gel electrophoresis analysis that two more fragments with a size of about $200 \mathrm{bp}$ and 


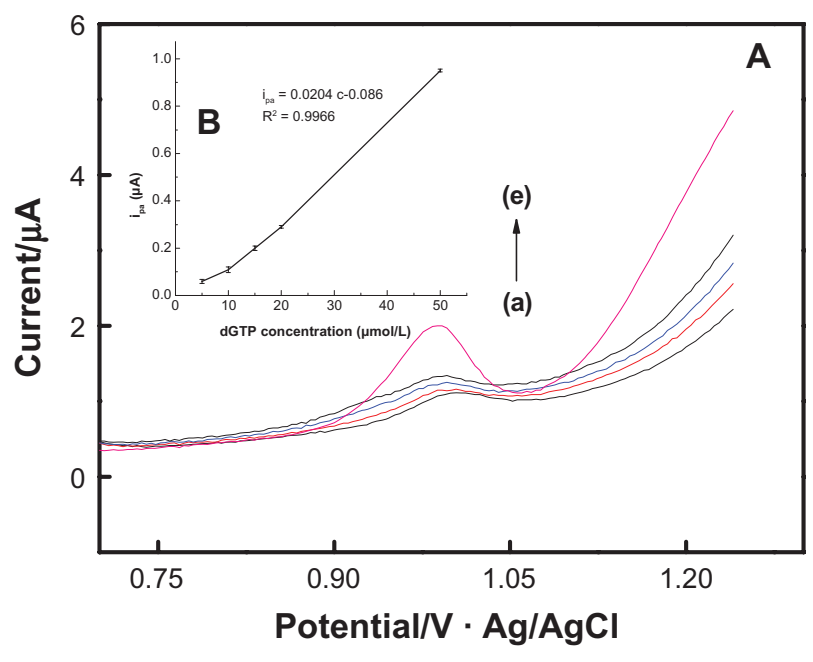

Figure 2 DPV diagram (A) of deoxy-guanine triphosphate of different concentrations on multiwalled nanotube-modified glassy carbon electrode and the working curve (B) reflecting the relationship between oxidation peak current and concentration change.

Abbreviations: dGTP, deoxy-guanine triphosphate; DPV, differential pulse voltammetric.

$800 \mathrm{bp}$ were amplified from the pancreatic cancer sample than the healthy control, as shown in Figure 3B. The results showed that the electrochemical sensor could be used to detect changes in dGTP quantity and thus could be used to screen for gene alterations associated with pancreatic cancer.

\section{Purification of sequencing results}

The differentially amplified bands (between the pancreatic cancer and healthy control reactions; $200 \mathrm{bp}$ and $800 \mathrm{bp}$ ) were purified, cloned, and sequenced (Figure 4). The underlined sequence in Figure 4 is consistent with amplification with random primer No. 2 (AACGGTCACT), and the associated sequence is a fragment of plasmid. This sequence was identical to that of the 3 ' end of a cyclin-dependent kinase gene of Homo sapiens located on chromosome 1.

\section{Genetic fingerprinting}

Using random primer combinations (the primer added to the PCR system is from \#1 to \#5), amplification was performed using peripheral blood DNA samples from healthy controls (gel electrophoresis lane A) or patients with pancreatic cancer (gel electrophoresis lanes B $\rightarrow \mathrm{G}$ ) as DNA templates under the same PCR conditions. The results showed that the resulting PCR products were significantly different, based on either agarose gel electrophoresis or electrochemical sensing technology for detection of the PCR-based substrate (dGTP) (Figure 5).

As can be observed in Figure 5, the different pancreatic cancer DNA templates that were amplified via arbitrarily primed PCR presented different banding patterns following gel electrophoresis, indicating a difference between individuals with pancreatic cancer. Furthermore, these differences could also be identified using the electrochemical sensor, which presented significantly different concentration curves.

\section{Discussion}

As the generation III human genetic mark, single nucleotide polymorphisms (SNPs) reflect the difference between individual phenotypes, disease susceptibility, and the response to drugs and the environment, for example. As such, SNPs are an ideal means for the study of malignant tumors and other complex diseases. ${ }^{13,14}$ Thanks to the optimization
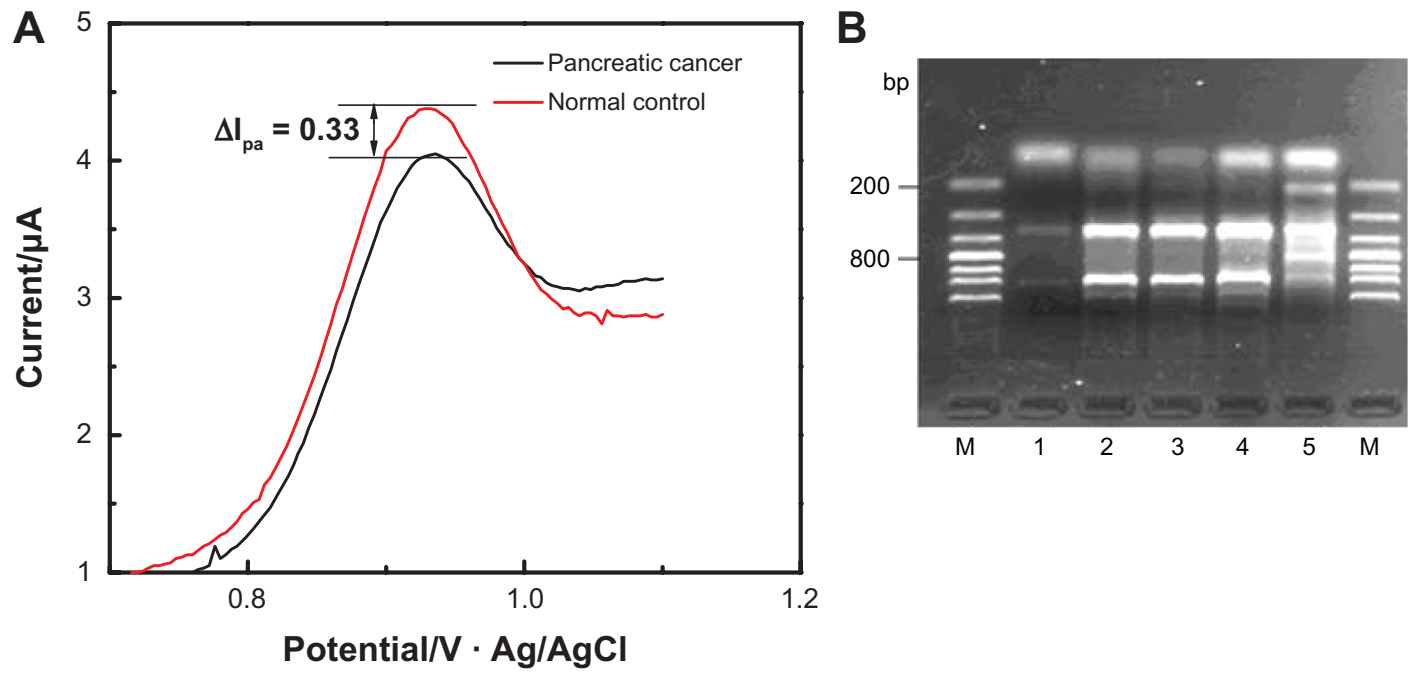

Figure 3 Diagrams of differential oxidation current between pancreatic
product (B) on multiwalled nanotube-modified glassy carbon electrode. 


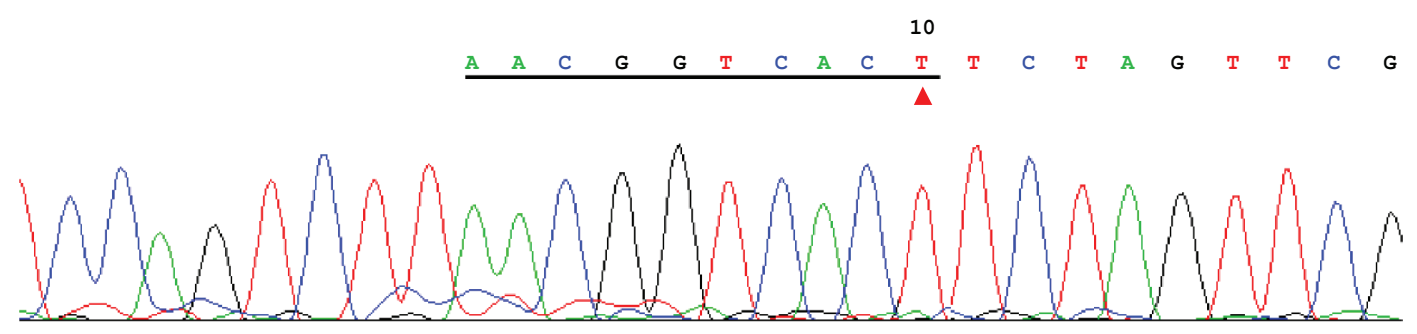

Figure 4 Result of clone sequencing of the differential polymerase chain reaction product.

of gene sequencing technology and the close cooperation between international research groups in recent years, casecontrol studies detailing the relationship between SNPs and cancer risk have been increasing rapidly. ${ }^{15}$ However, these types of studies are still limited by the current methodology. Compared with the human gene database and the complex varieties of human diseases, the number of SNPs/mutations clearly associated with human disease is limited. ${ }^{16}$

The development of interdisciplinary approaches promotes progress in gene testing technologies. In this study we developed a technical platform that combined arbitrarily primed PCR and nanoelectrochemical sensing for screening of pancreatic cancer susceptibility genes. There are many points to consider in respect of the use of RAPD in combination with electrochemical sensor analysis that have significantly improved the efficiency of screening for genetic alterations. In terms of PCR product identification, the traditional practice has been to interpret differential banding patterns following agarose gel electrophoresis. However, this method itself has many flaws, such as poor sensitivity and specificity. Furthermore, the more significant limitation lies in the fact that arbitrarily primed PCR utilizes

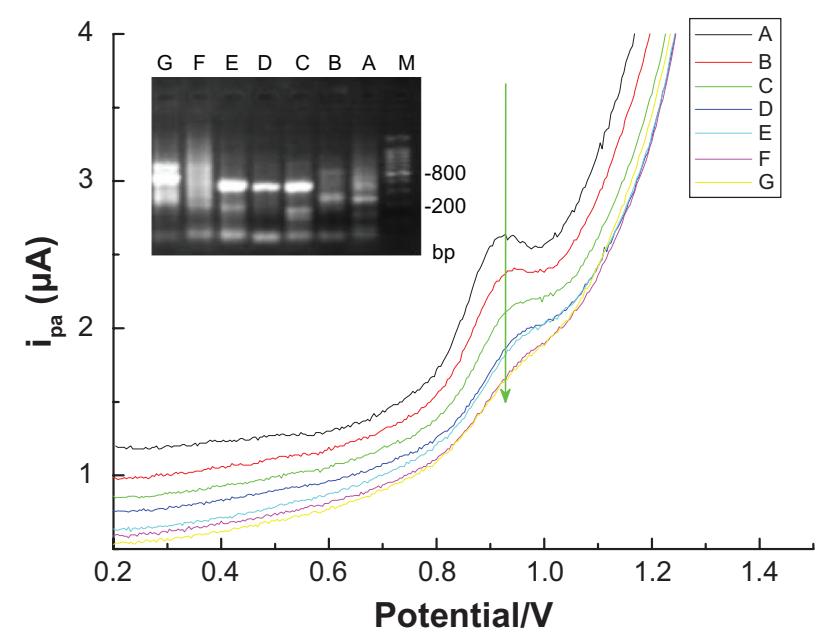

Figure 5 DPV curve generated from different pancreatic cancer samples amplified via arbitrarily primed polymerase chain reaction and detected using a multiwalled nanotube-modified glassy carbon electrode.

Abbreviation: DPV, differential pulse voltammetric short-sequence primers, and thus the products under different conditions would be significantly different. As such, it would be impossible to handle such a huge project using traditional technology. ${ }^{17}$ By using nanoelectrochemical sensing technology to detect arbitrarily primed PCR products or substrates, we screened for differentially amplified genes between patients with pancreatic cancer and controls and identified a cyclin-dependent kinase gene. This gene is involved in cell-cycle regulation and progression through the cell cycle. Mutations in this gene could lead to arrest in the G1 phase of the cell cycle and thus possibly influence the development of pancreatic cancer. ${ }^{18,19}$

With regard to this approach, another point to consider is that arbitrarily primed PCR technology is a new molecular marking technology based on traditional PCR, and the amplified fragment polymorphism reflects polymorphisms in the DNA. ${ }^{20-24}$ Any specific primer has its unique binding site in the DNA template sequence. Any insertion, deletion, or base mutation in the primer binding site within the DNA template may result in a change in the distribution of these specific binding sites and thus bring about a change in the quantity/ size of the amplification product. Specific primer sets can only test for DNA polymorphisms in specific areas of the genome; however, a series of primers can be used to expand the detection area to encompass the whole genome. Hence, RAPD could be used for polymorphism detection of the entire genome and for construction of genomic fingerprints. ${ }^{25,26}$ The experimental design depicted in Figure 6 shows the backward estimation of template-strand conditions based on the detection of reaction substrate consumption using nanoelectrochemical sensing technology.

In case of a base change at site 2 , the sequence no longer matches with the random primers, and the reaction does not produce product $\mathrm{B}$. Another point to consider is that this detection technology is based on determining the concentration of dGTP without introducing any foreign substance to the PCR system..$^{20,21}$ In this study, GCE surface-modified carbon nanomaterial was used for the study of the electrochemical behavior of guanine and dGTP at normal PCR 


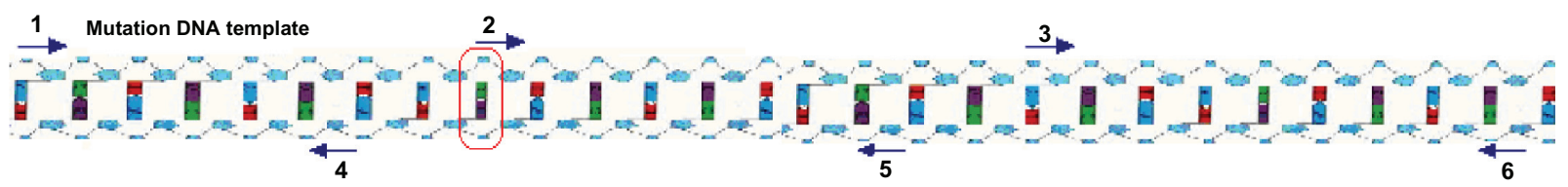

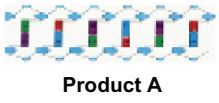

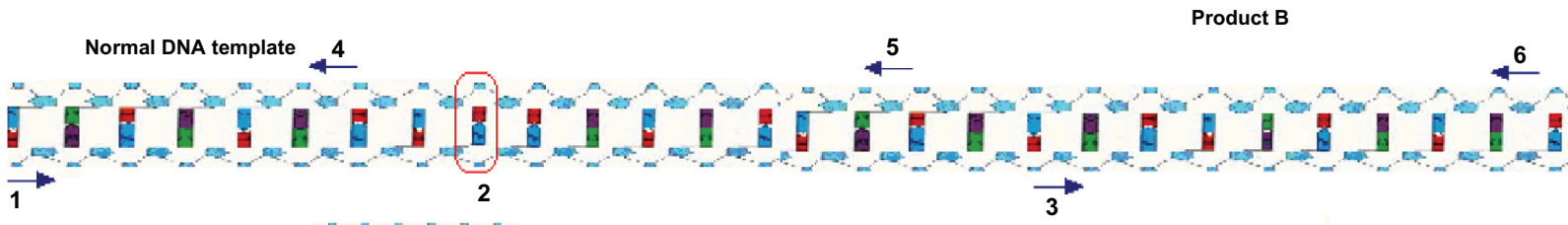

$11-1$

Product B

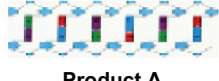

Product A

Figure 6 Schematic diagram of the screening of genetic alterations using random primers.

concentrations, and it provided a theoretical basis for the development of new DNA detecting methods and design of guanine oxidation-based biosensors. This method could have profound significance and application value to studies involving clinical medicine and genetic engineering. ${ }^{22,23}$

The development of pancreatic cancer is the result of environmental and genetic factors, and the poor understanding of the relationship between gene abnormalities and pancreatic cancer greatly restricts the application of molecular diagnoses for the early screening of high risk groups. Nanoelectrochemical sensors have unique oxidation electrical behaviors in terms of detection of PCR reaction substrates (dGTP), and the use of random primers generates different amplification products under different PCR conditions. In this study we estimated the difference in amplification product from the template by detecting substrate consumption after the amplification of DNA templates from the patients with pancreatic cancer and healthy controls under the same conditions. The results showed that the new design was effective at distinguishing genetic alterations. Although some defects are observed in this principle, this paper proposes a new method of studying the differential gene of complex diseases, and provides a valid example of applying carbon nanotubes to clinical gene study.

\section{Acknowledgments}

Financially supported by the Project Foundation of Fujian Provincial Education (JA10143), National High Technology Investigation Project Foundation of China (2008AA02Z433), National Natural Science Foundation of China (20975021, 20805006), and Major Program Foundation of Fujian Medical University (09ZD013).

\section{Disclosure}

The authors report no conflicts of interest in this work.

\section{References}

1. Okazaki T, Jiao L, Chang P, et al. Single-nucleotide polymorphisms of DNA damage response genes are associated with overall survival in patients with pancreatic Cancer. Clin Cancer Res. 2008; 14:2042-2048.

2. Pierce BL, Ahsan H. Genome-wide "pleiotropy scan" identifies HNF1A region as a novel pancreatic cancer susceptibility locus. Cancer Res. 2011;71:4352-4358.

3. Petersen GM, Amundadottir L, Fuchs CS, et al. A genome-wide association study identifies pancreatic cancer susceptibility loci on chromosomes 13q22.1, 1q32.1 and 5p15.33. Nat Genet. 2010;42:224-228.

4. Ekrami A, Samarbaf-Zadeh AR, Khosravi A, et al. Validity of bioconjugated silica nanoparticles in comparison with direct smear, culture, and polymerase chain reaction for detection of Mycobacterium tuberculosis in sputum specimens. Int J Nanomedicine. 2011;6: 2729-2735.

5. Yang T, Zhang W, Du M, Jiao K. A PDDA/poly(2,6-pyridinedicarboxylic acid)-CNTs composite film DNA electrochemical sensor and its application for the detection of specific sequences related to PAT gene and NOS gene. Talanta. 2008;75:987-994.

6. Rasooly A, Jacobson J. Development of biosensors for cancer clinical testing. Biosens Bioelectron. 2006;21:1851-1858.

7. Liu RH, Yang J, Lenigk R, et al. Self-contained, fully integrated biochip for sample preparation, polymerase chain reaction amplification, and DNA microarray detection. Anal Chem. 2004;76:1824-1831.

8. Cheng J, Gu YJ, Wang YJ, et al. Nanotherapeutics in angiogenesis: synthesis and in vivo assessment of drug efficacy and biocompatibility in zebrafish embryos. Int J Nanomedicine. 2011;6:2007-2021.

9. Li J, Qiu JD, Xu JJ, et al. Synergistic effect of Prussian blue grafted carbon nanotubes/poly(4-vinyl-pyridine) composites for sensitive amperometric sensing. Adv Funct Mater. 2007;17:1574-1580.

10. Lin LQ, Liu QC, Wang LM, et al. Enzyme-amplified electrochemical biosensor for detection of PML-RAR $\alpha$ fusion gene based on hairpin LNA probe. Biosens Bioelectron. 2011;28:277-283.

11. Nair KL, Jagadeeshan S, Nair SA, Kumar GSV. Biological evaluation of 5-fluorouracil nanoparticles for cancer chemotherapy and its dependence on the carrier, PLGA. Int J Nanomedicine. 2011;6:1685-1697.

12. Lao K, Xu NL, Straus NA. Whole genome amplification using singleprimer PCR. Biotechnol J. 2008;3:378-382. 
13. Loeb LA, Monnat RJ Jr. DNA polymerases and human disease. Nat Rev Genet. 2008;9:594-604.

14. Loeb LA. Human cancers express mutator phenotypes: origin, consequences and targeting. Nat Rev Cancer. 2011;11:450-457.

15. Wright FA, Strug LJ, Doshi VK, et al. Genome-wide association and linkage identify modifier loci of lung disease severity in cystic fibrosis at 11p13 and 20q13.2. Nat Genet. 2011;43:539-546.

16. Lange SS, Takata K, Wood RD. DNA polymerases and cancer. Nature Rev Cancer. 2011;11:96-110.

17. Feng K, Zhao J, Wu ZS, et al. High-sensitive electrochemical detection of point mutation based on polymerization-induced enzymatic amplification. Biosens Bioelectron. 2011;26:3187-3191.

18. Venter JC, Adams MD, Myers EW, et al. The sequence of the human genome. Science. 2001;291:1304-1351.

19. Gao F, Liu QC, Wang M, et al. Novel mutation of the cyclin-dependent kinase 4 gene in a Chinese patient with intimal sarcoma of the pulmonary artery. Chin Med J. 2009;122:1107-1109.

20. Oliveira-Brett AM, Vivan M, Ferandes IR, et al. Electrochemical detection of in situ adriamycin oxidative damage to DNA. Talanta. 2002;56:959-970.
21. Pedano ML, Rivas GA. Adsorption and electrooxidation of nucleic acidsm at carbon nanotubes paste electrode. Electrochem Commun. 2004;6:10-16.

22. Deféver T, Druet M, Rochelet-Dequaire M, et al. Real-time electrochemical monitoring of the polymerase chain reaction by mediated redox catalysis. J Am Chem Soc. 2009;131:11433-11441.

23. Li Q, Batchelor-McAuley C, Compton RG. Electrochemical oxidation of guanine: electrode reaction mechanism and tailoring carbon electrode surfaces to switch between adsorptive and diffusional responses. $J$ Phys Chem B. 2010;114:7423-7428.

24. Davey JW, Hohenlohe PA, Etter PD, et al. Genome-wide genetic marker discovery and genotyping using next-generation sequencing. Nat Rev Genet. 2011;12:499-510.

25. Atienzar FA, Venier P, Jha AN, Depledge MH. Evaluation of the random amplified polymorphic DNA (RAPD) assay for the detection of DNA damage and mutations. Mutat Res. 2002;521:151-163.

26. Singh KP, D Roy. Identification of novel breast tumor-specific mutation(s) in the q11.2 region of chromosome 17 by RAPD/AP-PCR fingerprinting. Gene. 2001;269:33-43.
International Journal of Nanomedicine

\section{Publish your work in this journal}

The International Journal of Nanomedicine is an international, peerreviewed journal focusing on the application of nanotechnology in diagnostics, therapeutics, and drug delivery systems throughout the biomedical field. This journal is indexed on PubMed Central, MedLine, CAS, SciSearch $\AA$, Current Contents ${ }^{\circledR} /$ Clinical Medicine,

\section{Dovepress}

Journal Citation Reports/Science Edition, EMBase, Scopus and the Elsevier Bibliographic databases. The manuscript management system is completely online and includes a very quick and fair peer-review system, which is all easy to use. Visit http://www.dovepress.com/ testimonials.php to read real quotes from published authors. 